\title{
EFFECT OF ROLE CONFLICT AND ROLE OVERLOAD TO BURNOUT AND ITS IMPACT ON CYBERLOAFING (STUDY ON PT PLN (PERSERO) PUSAT MANAJEMEN KONSTRUKSI)
}

\author{
Wenefrida Ardhian Ayu Hardiani1 ${ }^{1}$, Eddy Rahardja², Ahyar Yuniawan ${ }^{3}$ \\ ${ }^{1}$ Master of Management, Faculty of Economics and Business, Diponegoro University \\ ${ }_{2}^{2}$ Master of Management, Faculty of Economics and Business, Diponegoro University \\ ${ }^{3}$ Master of Management, Faculty of Economics and Business, Diponegoro University
}

\begin{abstract}
Cyberloafing is one of the employee's counterproductive behavior by using mobile phone and office internet facility for personal use during working hours. Cyberloafing behavior is caused one of them by the psychological condition of employees, namely burnout. The cause of this burnout is due to role conflict and role overload. If the behavior of cyberloafing continues to be done will hamper the productivity of employees and eventually will have a negative impact on the company. The problem in this research is how to decrease cyberloafing by seeing role conflict, role overload, and burnout.

The sample of this study amounted to 150 respondents. Sample determination was done by census technique. Respondents in this research are employees of PT PLN (Persero) Pusat Manajemen Konstruksi Semarang. The analysis tool used is Structural Equation Modeling (SEM) in AMOS 22 program.

Based on five hypotheses tested, there are four accepted hypotheses. Role conflict has a significant effect on cyberloafing, role overload has no effect on cyberloafing, role conflict and burnout has a significant effect on burnout, and burnout has a significant effect on cyberloafing. In an effort to decrease the level of cyberloafing, good human resource management is required. Purpose of Human resource management is to avoid role conflict, role overload, and burnout affecting cyberloafing.
\end{abstract}

Key Words : Cyberloafing, Role Overload, Burnout, Role Conflict, HR Management.

\section{INTRODUCTION}

PT PLN (Persero) Pusat Manajemen Konstruksi is one of PLN's business units engaged in construction management located at Jalan Slamet No.1 Gajah Mungkur, Semarang. As a large PLN unit with 5 branch offices covering all areas of Indonesia, PT PLN (Persero) Pusat Manajemen Konstruksi or so-called PLN Pusmankon has a large number of employees. Labor productivity affects the development of the company so it is necessary good management in order to realize the balance of employee needs and demands of the company. Several factors that affect labor productivity are one of them caused by employee counterproductive behavior like cyberloafing. Cyberloafing is caused one of them by the psychological condition of employees, namely burnout. The cause of this burnout is due to role conflict and role overload. 
Role conflict is a conflict that arises due to the existence of several orders/roles are implemented simultaneously so that in its implementation ignore the others command/roles. Role conflict can cause burnout, causing deviant behaviors that can degrade performance. Role conflict and role overload can trigger burnout. The results of Yagil et al (2008) showed that job stressors (role conflict, role ambiguity, and role overload) were burnout predictors. According to Thanacoody et al (2009) concluded that the consequences of role conflict are burnout. This means role conflict has a strong influence on stress that eventually triggers burnout. In addition to role conflict, burnout can also be triggered by a role overload.

According to Bolino and Turnley (2005) states that role overload occurs because an employee has too much work to do under the pressure of a very tight schedule and not in accordance with ability. When too much work to do causes physical and mental exhaustion, even the saturation and stress of work load, coupled with the feeling that the skill does not meet the demands of the task, it will trigger burnout. As Virick and Casper (2007) claim that role overload leads to high physical and psychological fatigue. Research conducted by Prijayanti (2015) on the effect of workload and social support on burnout shows that there is a significant role overload influence on burnout.

Burnout is part of stress (Luthans, 2005). According to King et al (1995) states that the stress on individuals in the workplace that takes place continuously will cause emotional fatigue and low motivation that will affect the incidence of burnout. As Hardiyanti (2013) argues that burnout is an epidemic that plagues the world of work, shows how the emotional state of individuals who feel tired and mentally saturated due to high demands and work pressure. According to Maslach and Jackson (1981) burnout is a state of employee feeling emotionally tired and cynicism in various types of work. Burnout can also be defined as an employee's condition of feeling depressed, boredom, and dissatisfaction towards work that results in emotional fatigue and physical depression (Pines and Kafry, 1978). Burnout on employees is influenced by poor work environment, lack of support from leaders/supervisors, unhealthy competition among co-workers, role conflict, role ambiguity, role overload, and others. This burnout will lead to counterproductive behavior one of which is cyberloafing.

According to Gruys and Paul (2003) counterproductive behavior is a good activity done intentionally or unintentionally that hinders the performance of individuals, others, and organizations. One of the counterproductive work behaviors that are often done by employees is cyberloafing, especially for those who work by using computer facilities connected to the internet. Cyberloafing is an act of corporate internet abuse for personal affairs, such as reading information on news sites, games, entertainment, checking personal email, facebook, and browsing other websites. This behavior violates organizational norms and threatens the well-being of the organization and its members (Robinson and Bennet, 1995). According to Askew (2012) concluded that cyberloafing is an employee's behavior in using various types of computers (desktop, cell-phone, tablet, ipad) both privately owned and corporate during working hours for unrelated activities. Cyberloafing can be affected by work stressors (role ambiguity, role conflict, role overload) and organizational sanctions (Blanchard and Henle, 2008). 
From the previous researches still found some differences in research results between role conflict variables, role overload, burnout, and cyberloafing are still debated among others according to the table below.

Table 1

\section{Research Gap}

\begin{tabular}{lll}
\hline Aghaz dan Sheikh (2016) & Burnout of cyberloafing & Significant to office workers. \\
\hline Anindita (2013) & Role conflict of cyberloafing & Significant to office workers. \\
\cline { 2 - 3 } Bacharach et al (1991) & Role overload of cyberloafing & Not significant to office workers. \\
\hline Prijayanti (2015) & Role overload of burnout & Sot significant to nurses. \\
\cline { 2 - 3 } Lim (2002) & Cyberloafing & $\begin{array}{l}\text { Cyberloafing has a positive impact on } \\
\text { the company }\end{array}$ \\
\hline Permatasari (2010) & Cyberloafing & $\begin{array}{l}\text { Cyberloafing has a negative impact on } \\
\text { the company }\end{array}$ \\
\hline
\end{tabular}

Employees in PT PLN (Persero) Pusat Manajemen Konstruksi tend to experience boredom and burnout, because besides routine work, they also have to share role in office (role conflict). Therefore, employees tend to do cyberloafing because it is considered the easiest to eliminate burnout and emotional burnout especially with the availability of internet facilities in each computer.

Unwitting cyberloafing can disadvantageous the company. This is because cyberloafing can cause poor performance on the employee, which ultimately will harm the company. Employees will be engrossed in using their working time by doing things like playing games, opening personal emails, chatting or communicating with friends, and others. This will ultimately lead to poor performance for the company.

of the various factors that influence cyberloafing, the authors are interested to examine the influence of role conflict and role overload on burnout and its impact to cyberloafing (Study at PT PLN (Persero) Pusat Manajemen Konstruksi Semarang).

\section{LITERATURE REVIEW \\ 1. Cyberloafing}

Cyberloafing is one of the deviant behavioral behaviors that fall into the category of production deviation. Cyberloafing according to Blanchard and Henle (2008) is defined as the activity of using internet and email facilities at work that employees deliberately do to open sites that do not support work during working hours. According to Askew (2012) cyberloafing is the behavior of employees in using various types of computers (desktop, cell-phone, tablet, ipad) both private and corporate during working hours for activities that are not related to work.

Factors affecting cyberloafing are individual, organizational, and situational factors (Ozler and Polat, 2012). Individual factors include perceptions and attitudes, personal traits, habits and addictions to the Internet, demographic factors, willingness to engage, and personal code of ethics. Liberman et al (2011) argues that individuals who have a positive attitude toward 
computers have a tendency to use computers for personal reasons in place (cyberloafing). Individuals who feel that Internet use can facilitate their work, tend to engage in cyberloafing (Vitak et al, 2011). Personal traits such as shyness, loneliness, isolation, self-control, self-esteem, locus of control can influence internet usage patterns. The results show that shy and less confident individuals tend to engage in Internet use. According to Vitak et al (2011) the relationship between cyberloafing habits can predict individual behavior. The higher the level of internet addiction, the higher the level of internet abuse by individuals. Individual normative beliefs reduce the desire of individuals to do cyberloafing.

Organizational factors include managerial support, peer co-workers perceptions of cyberloafing norms, work attitude of employees affected by environmental factors, and job characteristics. Cyberloafing action is an emotional response of employees who feel that they have failed. This resulted in employee work attitude may affect cyberloafing (Liberman et al, 2011).

Situational factors trigger the emergence of cyberloafing. The existence of formal policies and organizational witnesses can reduce cyberloafing. According to Blanchard \& Henle (2008) that cyberloafing behavior can be affected by work stressors (role conflict, role ambiguity and role overload), and organizational sanctions.

\section{Burnout}

Burnout is a state of emotional, mental, and physical exhaustion caused by excessive and prolonged stress in work (Maslach, 1998). Burnout is a psychological term used to describe feelings of failure or lethargy due to demands that incriminate the individual's energy and ability. The term burnout was introduced by Herbert Freudenberger in 1973. In explaining the term burnout, Freudenberger gives an illustrative example of the feelings of someone who has this syndrome like a magnificent building together with activity in it then burned out and the outer frame after burning, just like a burnout person, from the outside everything is fine but inside it is empty like a burning building illustrated earlier. Burnout is depicted as when one tries to try to achieve an unrealistic goal then at last one is depleted of energy and experiences a state of loss of feelings about himself towards others (Gehmeyr, 1993).

Freudenberger defines burnout as a form of fatigue that arises because individuals who work too hard (both time and effort), dedicated, and do not give priority to their needs and desires. (Farber, 1991). It makes them feel the pressure. The origin of such pressure from within themselves, others around, customers, coworkers, and others. This pressure will create a sense of guilt that encourages them to work harder. If the reality does not support the desired conditions then they will work with all their might to achieve that desire, so that they will experience fatigue and frustration if the desire has not been achieved.

According to Hess (1992), burnout is not a disease but it is a reaction/response to what is hoped with an unrealistic purpose towards a change of expected condition; jobs that are filled with emotional demands, as well as long-term goals that are difficult to achieve. According to Maslach, the main source of the emergence of burnout is due to stress that develops simultaneously. Work environment factors are also very influential the emergence of burnout.

\section{Role Conflict}


Understanding of role conflict according to Robbins (2001) is a situation where a person faced with different role expectation. According to Wolfe and Snoek (1962), role conflict arises because of the existence of two or several different orders received simultaneously, the execution of one of the orders will ignore the other command. Or it can be concluded that role conflict as a mismatch between expectations associated with a role in extreme conditions and the presence of some role expectations will be so contradictory that other roles are unworkable. The emergence of role conflict is due to the mismatch of role pressures (Bamber et al., 1989).

Several factors may influence role conflict on organizational commitment relationships. Stress due to role demands and uncertainty in work can lead to job dissatisfaction and will increase tension, turn over to other companies, and reduce commitment (Lambert et al., 2007).

Role conflicts can be defined as conflicts that occur because a person performs his role simultaneously so that will lead to nonfulfillment of one role due to fulfillment of other roles.

Here are the types of role conflict according to Khan et al. (1964), as follows:

1) Intrasender conflict

Intrasender conflict arises from a boss who gives unsuitable tasks/responsibilities to his subordinates.

2) Intersender conflict

Intersender conflict is caused by the difference of expectation from one person or group that experienced conflict with the expectation of other people/group. Example: a leader authorizes supervisors to speed up the production process. In this case described every effort in obeying the command will cause difficulties.

3) Person-role conflict This conflict arises when there is a role demands to carry out work that is contrary to the values of the individuals it embraces. For example: an employee who is sent to give a bribe to a certain county official, an employee will feel if the task is a very unethical task, but on the other hand consideration of career path will make the employee must perform such action.

4) Role Overload Conflict

A condition that arises when an individual faces a task/command from superiors that is impossible to complete within a given time frame and within specified quality limits.

5) Role Ambiguity

In such circumstances it arises when a person obtains an incomplete and unclear information about his responsibilities in the job. Therefore one don't know what to do.

6) Inter-role conflict

Inter-role conflict arises when various roles are executed by a person causing the emergence of different demands.

\section{Role Overload}

There are 2 meanings of role overload that are the qualitative role load and the quantitative role load. The burden of a qualitative role when an individual feels that his or her expertise can not meet the demands assigned, while the quantitative role load occurs when an individual has difficulty completing tasks within a given time (Bhanugopan and Fish 2006). Role overload according to Abraham (1997) is a conflict that comes from a necessity which is an expectation if one can perform a task in the presence of time limits that may be 
difficult to resolve. Roles overload are the inability of employees to complete their tasks because of too high yield standards, and completion of tasks with inadequate provision of time (Barney \& Griffin in Permatasari, 2010).

Role overload occurs when an employee has many tasks to be completed under limited time and pressure so that it does not match the ability of the employee to complete the task. When too much work will cause physical and mental fatigue, even saturation and stress due to workload, let alone feel personal ability can not solve the task demands that cause burnout. Roles overload can cause negative outcomes in work such as turnover (Issaksson \& Johansson, 2003) and tensions that include dissatisfaction in work and anxiety (Henle \& Blanchard, 2008).

\section{METHOD}

The population in this research is employees of PT PLN (Persero) Pusat Manajemen Konstruksi in Semarang as many as 150 people. The sampling technique in this study is by census. The analysis tool used is SEM (Structural Equal Modeling).

According to Hair et al (1995) in Ghozali (2014) there are seven steps in performing stages of modeling and structural analysis. Here are 7 steps of using SEM with AMOS 22.0 software, that is Developing Model Based on Theory at this step have to do literature study to get the theoretical model that will be developed by using SEM analysis tool, second step is Conducting Path Diagram (Path Chart), third step is Conducting Preparation Structural Equation, fourth step is Selecting Matrix Input Type and Proposed Model Estimation, Fifth step is Problem Identification of Structural Model, Sixth and Seventh steps are Evaluation of criteria or Goodness of Fit and Interpretation and Modification of Model.

\section{DISCUSSION}

Role conflict has been shown to have the greatest effect on cyberloafing. This is evidenced from the loading factor is greater than other factors. The results of this study in accordance with research Anindita (2013), Henle and Blanchard (2008), Permatasari (2010) which shows that the influence of role conflict on cyberloafing.

It can also be explained from the situation in the field based on the respondent's answer about the indicator of the questionnaire of role conflict is quite high, namely:

1) Respondents often do work done in different ways.

2) Respondents often override a rule so that the work done quickly resolved.

Role conflict that happened in PT PLN (Persero) Pusat Manajemen Konstruksi have an effect on cyberloafing. Every employee besides doing routine tasks also performs team tasks. Many employees are confused in sharing roles within the company. In this case they are looking for an outlet to resolve the role conflict that occurs, so they tend to conduct cyberloafing that is use of internet facilities for personal gain. To reduce the problem companies should reorganize work programs such as reorganizing weekly, monthly, and semiannual planning in accordance with the competence and capacity of employees so as to reduce the role conflict experienced by employees. These steps in addition to reducing role conflict themselves, will also reduce cyberloafing. It will also be able to improve employee performance which means to improve the company's performance further.

Role overload has no effect on cyberloafing in PT PLN (Persero) Pusat Manajemen Konstruksi. This is because that with many tasks, PLN Pusmankon employees 
are very busy with job demands that require them to complete the work in accordance with the target time and quality that is determined. This is in accordance with the research of Henle and Blanchard (2008), Permatasari (2010) which shows that role overload has no effect on cyberloafing. High role overload do not cause cyberloafing, because employees will feel busy and do not even have time to think about other things outside of their work. However, with the high workload will cause an employee will experience a prolonged stress and later will continue to burnout. This stress will make employees become easily tired, sick, and depressed. Decline in employee performance becomes an impact that is associated with the sustainability of the company. Forward the retreat of a company depends on human resources in it. Therefore it is very important for companies in managing the human resources that are in it. One way is to make employees feel comfort and productive in working. In doing the work, the company should pay more attention to whether the work is in accordance with the ability of employees and whether the deadline is determined accordingly or not. Do not just to gain profit alone, the company ignores its employees. This is very important because it can determine the sustainabilty of the company.

Role conflict has a positive effect on burnout in PT PLN (Persero) Pusat Manajemen Konstruksi. This result is in accordance with research Bacharach et al (1991) which states that role conflict positively affects burnout. In accordance with the situation in the field based on respondents' answers about the indicators of role conflict are quite high as follows:

1) Respondents often do jobs that tend to be accepted by one party but are not accepted by the other party.
2) Respondents often work with uncertain or unclear directions.

High role conflict will result in a person experiencing emotional fatigue so as to perform actions to eliminate the fatigue or emotional fatigue that occurred. This role conflict will make an employee to be confused and depressed so that later he will experience burnout. Burnout is if not addressed will cause a very large side effects for the company.

In doing a job, employee must be able to work productively. Productive work can only be achieved if the environment supports employee work. Among other employees are not depressed or having a conflict in doing their duties. If a person is confused about the task (role conflict), then the person will experience stress and will then continue to a condition called burnout.

The importance of setting up work programs in the office so that employees become more focused in work. In addition, refreshment activities should be done regularly to reduce emotional saturation and fatigue that occurs in employees such as regular hobby activities, sports activities, employee gathering, and entertainment competitions conducted at certain events.

Employees who avoid burnout are employees who can work optimally and productively which means to be a benefit for the company itself.

Role overload positively affect the burnout of PT PLN (Persero) Pusat Manajemen Konstruksi. This result is in accordance with Prijayanti (2015), Yagil et al (2008) study which states that role overload has a positive effect on burnout. With so many jobs demanded with quality constraints and time determined to cause PLN Pusmankon employees experiencing emotional fatigue or burnout. This is in accordance with the respondent's answer 
about the revelation of high role overload questionnaire, namely:

1) Respondents often get another job before their job is done

2) Respondents often do tasks that exceed of their ability

Role overload is one obstacle in the progress of the company. A person who experiences a role overload will feel very tired and stressed out and then continue to burnout. Burnout itself is a state where a person experiences emotional fatigue. This burnout will lead to an action that employees do outside the interests of the company. Like opening articles, chatting, online games, shopping online during work hours. This cyberloafing will decrease employee performance and will be dangerous for the sustainability of the company. Companies should re-correction work by looking at weekly, monthly, and semiannual job planning. Whether a job can be completed with time and quality target determined, whether the number of employees is adequate in doing the job, whether the job is in accordance with the competencies of employee. This needs to be done because of the importance of the role of human resources in a company. With the reexamination, employees will feel less depressed and they can improve their performance, which means improving the company's performance further.

Burnout positively affects the cyberloafing of PT PLN (Persero) Pusat Manajemen Konstruksi. This result is consistent with Aghaz and Sheikh (2016) studies which state that burnout has a positive effect on cyberloafing. This is in accordance with respondents answers about the revelation of a high burnout questionnaire, namely:
1) Respondents often feel discouraged by work that can not be completed properly

2) Respondents often experience fatigue (physical) after completion of work

3) Respondents often feel unsure about doing a job

Burnout is a form of emotional fatigue or saturation that will make a person to do something to reduce the saturation. One such action is cyberloafing. Burnout itself is a form of emotional fatigue where the characteristics are as follows: often feeling discouraged, physical exhaustion, and not sure in doing a job. This burnout will lead to cyberloafing, an act of using the office's internet facility for personal use during working hours. Cyberloafing if left unchecked will have an adverse effect on employee performance and will affect the company's sustainability.

Companies should create refreshing activities that can help employees to minimize burnout. Refresher activities should be done routinely so that the saturation that occurs in the work can be reduced. One example of refresher activities is family gathering, gymnastics together, hobby clubs, and etc. A healthy and fit employee both physically and mentally will be able to work optimally. So that will be able to improve personal performance and will help the company to get a excellence achievement.

\section{CONCLUSION AND SUGESTION}

\section{Conclusion}

Role conflicts have the greatest effect on the incidence of cyberloafing over burnout. Someone who experiences high role conflict will tend to do cyberloafing that is using internet facility for its own sake in working hours. Role overload does not affect to the emergence of cyberloafing. A person who experiences high role overload will not 
commit cyberloafing. Role conflict affects burnout. The higher the role conflict experienced by employees the more burnout that is a form of emotional fatigue. Roles overload affect the incidence of burnout. An employee who has a high role overload will progressively experience some form of emotional fatigue or burnout. Burnout has an effect on cyberloafing. The higher the burnout experienced by someone then the level of cyberloafing will be high.

\section{Suggestion}

This study has several limitations that will be presented below. This study does not take into consideration the habits of a person in his daily social life, the study only analyzes the cyberloafing problem from the point of view of employees who do daily work in the office, but does not explore from other perspectives such as top management / from the perspective of the workers, the study only uses samples from employees who have job desks in the office and does not use samples from employees who work in the field so as not to describe or predict the problem of cyberloafing of employees as a whole in a company.

On the research agenda that will be expected data by researchers is as follows future research can be done by considering the habits of a person, future research is done not only from one point of view of employees in the office, but it is recommended at the same time from the point of view of other employees such as company officials, in the field, etc., future research can use samples not only from the office but also use samples from the field work so can describe the problem of cyberloafing in whole company.

\section{REFERENCES}

Abraham, R. (1997). Thinking styles as moderators of role stressor-job satisfaction relationships. Leadership \& Organization Development Journal, 18(5), 236-243.

Aghaz, A., \& Sheikh, A. (2016). Cyberloafing and job burnout: An investigation in the knowledge-intensive sector. Computers in Human Behavior, 62, 51-60.

Askew, Kevin Landon .2012. The relationship Between Cyberloafing and Task Performance and an Examination of Theory of Palnned Behavior as a Model of Cyberloafing. University of South Florida . Dissertation

Bhanugopan, R., \& Fish, A. (2006). An empirical investigation of job burnout among expatriates. Personnel Review, 35(4), 449-468.

Blanchard, Anita L \& Christine A Henle . 2008. Correlates of Different Form of cyberloafing : The role of norm and external locus of control. Computers in human behaviour 24 (2008) 1067 - 1084.

Bolino, Mark C \& William H Turnley.2005. The Personal Costs of citeenship behaviour : The Relationsip Between Individual Initiative and Role Overload, Job Stress, and Work Family Conflict. Journal of Applied Pschology .Vol.90, No.4, 740-748.

Farber. (1985). The measurement of experienced burnout. Journal of Occupational Behavior.Vol.2,99-113. 
Farber, B. A. (1991). Crisis in education: Stress and burnout in the American teacher. JosseyBass.

Ferdinand, A. (2002). SEM dalam Penelitian Manajemen: Edisi 2. Semarang: Badan Penerbit Universitas Semarang.

Freudenberger, H. J., \& Richelson, G. (1981). Burn-out: The high cost of high achievement. Bantam Books.

Gehmeyr A. (1993). Burnout. http://www.anbg.gov.au/fun/burnout.html. (14 Aug 2000).

Ghozali, Imam.(2016). Model Persamaan Struktural Konsep dan Aplikasi dengan Program AMOS 24(Edisi 7) .Semarang: Universitas Diponegoro.

Gruys, Mellisa \& Paul R Sackett.2003. Investigating the dimensionality of counterproductive work behaviour. International Journal of selection and assesment vol 11 no 1.

Hair, J. F., Anderson, R. E., Babin, B. J., \& Black, W. C. (2010). Multivariate data analysis: A global perspective (Vol. 7). Upper Saddle River, NJ: Pearson.

Henle, C. A., \& Blanchard, A. L. (2008). The interaction of work stressors and organizational sanctions on cyberloafing. Journal of Managerial Issues, 383-400.

Herdiati, Meilisa Fani.2014. Pengaruh Stressor Kerja dan Persepsi Sanksi Organisasi Terhadap Perilaku Cyberloafing di Universitas Jember. Universitas Jember.

Isaksson, K., \& Johannson, G. (2003). Managing older employees after downsizing. Scandinavian Journal of Management, 19(1), 1-15.

Kahn, R. L., Wolfe, D. M., Quinn, R. P., Snoek, J. D., \& Rosenthal, R. A. (1964). Organizational stress: Studies in role conflict and ambiguity.

King, L., King, D., Leskin, G., \& Foy, D. (1995). The Los Angeles Symptom Checklist: A self-report measure of posttraumatic stress disorder. Assessment, 2, 1-17.

Lambert, E. G., Hogan, N. L., \& Griffin, M. L. (2007). The impact of distributive and procedural justice on correctional staff job stress, job satisfaction, and organizational commitment. Journal of Criminal Justice, 35(6), 644-656.

Liberman, Benjamin et al. 2011. Employee job attitudes and organizational characteristic as predictors of cyberloafing. Computers in human behavior 27(2011)2192-2199

Lim, V. K., \& Chen, D. J. (2012). Cyberloafing at the workplace: gain or drain on work?. Behaviour \& Information Technology, 31(4), 343-353.

Luthans, Fred.(2005). Perilaku organisasi, Edisi Sepuluh, Diterjemahkan oleh : Vivin Andhika Yuwono; Shekar Purwanti; Th.Arie Prabawati; dan Winong Rosari. Penerbit Andi, Yogyakarta. 
Maslach, C. (1998). A multidimensional theory of burnout. Theories of organizational stress, 68

Maslach, Christina \& Susan E Jackson.1981. The Measurement of Experienced Burnout. Journal Of Occupational Behaviour. Vol. 2, $99-113$

Maslach, C., Schaufeli, W. B., \& Leiter, M. P. (2001). Job burnout. Annual review of psychology, 52(1), 397-422.

Ozler, Derya Ergun and Polat Gulcin.2012. Cyberloafing Phenomenon In Organizations : Determinants and Impacts. International Journal of Business and goverment studies .Vol 4, No.2, 2012 ISSN :2146-0744

Pines, A., \& Aronson, E. 1983. Combatting burnout. Children and Youth Services Review, 5(3), 263-275.

Pines, Ayala \& Ditsa Kafry .1978. Occupational tedium in social service. National Association of Social Workers

Permatasari, M. (2010). Pengaruh work stressorpada perilaku cyberloafingkaryawan dengan sanksi organisasi sebagai pemoderasi (Studi pada PT. PLN (PERSERO) APJ SURAKARTA), Universitas Sebelas Maret).

Prijayanti, Isnia.2015. Pengaruh Beban Kerja dan Dukungan Sosial Terhadap Burnout pada Karyawan PT X. Universitas Islam Negeri Syarif Hidayatullah.

Robbins,Stephen.P. (2006) .Perilaku Organisasi (Drs.BenjaminMolan) , Edisi Bahasa Indonesia,Klaten:PT Intan Sejati.

Schaufeli, W. B., Maslach, C. E., \& Marek, T. E. (1993). Professional Burnout: recent developments in theory and research. Taylor \& Francis.

Thanacoody, P.R., Bartram, T., dan Casimir, G. (2009), The Effect of Burnout and Supervisory Social Support on the Relationship between Work-Family Conflict 8 and Intention to Leave, Journal of Health Organization and Management, Vol. 23, No. 1, hal. 53-69.

Vitak, J., Crouse, J., \& LaRose, R. (2011). Personal Internet use at work :Understanding cyberslacking. Computers in Human Behavior, 27, 1751- 1759.

Virick, M., Lilly, J., \& Casper, W. (2007), Doing more with less: An analysis of work life balance among layoff survivors, Journal of Career Development International. Vol. 12, No 5.

Wolfe, D. M., \& Snoek, J. D. (1962). A study of tensions and adjustment under role conflict. Journal of Social Issues, 18(3), 102-121.

Yagil, D., Luria, G., dan Gal, I. (2008), Stressors and resources in customer service roles: Exploring the relationship between core selfevaluations and burnout, International Journal of Service Industry Management, Vol. 19, No. 5, hal. 575-595. 